\title{
Re-codification of the Civil Law of Ukraine: On the Way to European Integration
}

\author{
Vasyl Tatsiy \\ Full Doctor in Law, Professor, Honorary President of the National Academy \\ of Legal Sciences of Ukraine, Rector`s Advisor of the Yaroslav Mudryi \\ National Law University, Kharkiv, Ukraine \\ vasyl.tat@unesp.co.uk
}

In Ukraine's foreign policy, European integration is one of the highest priorities. This applies to all areas that are controlled by the authorities, as well as those supported by public organisations. When analysing and observing social processes that have been taking place in the past few years, to a certain extent, one can track the impact of European integration processes on society. There is active work taking place with young people in educational, health and social projects. Changes are being made in support of people with disabilities, namely, the needs of such people are beginning to be considered when constructing buildings and laying roads, and in the technical planning of cities, but what is more significant is a change in the attitude of society towards such people.

The main strategic document of the European integration processes is the Association Agreement between Ukraine and the European Union. This agreement spells out Ukraine's obligations to the European Union, as well as what the European Union will contribute to on the path to European integration. This issue demonstrates how European integration has influenced and can affect Ukrainian legislation in the field of civil law. The essence of the Civil Code of Ukraine is presented, as well as how changes are taking place in financial markets, in the protection of civil rights, intellectual property and inheritance. Below we offer a closer look at the research vectors that are presented in this issue.

Nataliia S. Kuznietsova, Oleksandr V. Petryshyn and Denys S. Pylypenko studied the Civil Code of Ukraine, namely the history of its creation, innovations that are occurring due to European integration and the conceptual foundations of the Code. The authors thoroughly analysed the code from the 
standpoint of how its provisions correspond to the trends in the development of civil society and its compliance with European integration processes. Researchers make conclusions in relation to the need to recodify the Civil Code of Ukraine, taking into consideration the experience of European countries.

Authors Anatolii S. Dovgert, Viktor Ya. Kalakura and Nataliia V. Vasylyna analysed which factors and preconditions justify the need for the re-codification of the Civil Code of Ukraine, as well as the extent of their use and validity. The paper deals with theoretical and practical problems of re-codification in the field of civil law. Re-codification is viewed as a process that is used to indicate significant systemic innovations in the content and structure of the current code (or group of codes and laws) without creating a new one.

In the study of Valentina I. Borisova, Igor V. Borisov and Farkhad S. Karagussov, the effect of European integration on the legislative acts regulating the activities of financial institutions is investigated. The authors conducted a scientific development of the legal structure of the legal forms of financial institutions in the financial services market, demonstrating the legislative structure as a legal mechanism for regulating the legal and economic interests of participants in financial institutions.

Nataliya M. Onishchenko, Tatyana I. Tarakhonych and Oleh L. Bohinich investigated the participation of state structures in legal relations between individuals. The study examines the nature of the state, in particular the Ukrainian state and the countries of the European Union, and which legal freedoms are present in a particular state. The authors suggest that the active process of re-codification of the civil legislation of Ukraine may lead to a revision of the foundations of understanding the state as a participant in civil relations.

Subjective law has been studied by Maidan K. Suleimenov, Oleksii O. Kot and Serhii O. Pohribnyi. The authors analysed the pan-European dimensions that have taken place in civil legislation in the field of their implementation and protection. The study focuses on the analysis of subjective patterns in various manifestations. As a result of their investigation, the authors presented conclusions regarding the quality of protective methods that exist in subjective civil law in Ukraine and in the countries of the European Union. Furthermore, the study focuses on the need for constant systematic analysis of the mechanism of legal regulation.

Vitaly L. Yarotskiy, Nataliia V. Fedorchenko and Iryna I. Puchkovska investigated the issue of re-codification of the concept of ensuring the human right to life and health in the Civil Code, namely, determining the time when such rights arise in a person. Also, the authors propose and argue for the introduction of the concept of 'special civil legal capacity' in the Civil Code. According to researchers, the determination of the time when a person has the right to 
life and health, as well as the emergence of special civil legal capacity, can significantly affect the laws of Ukraine regarding the rights to inheritance.

Roman I. Tashian, Bohdan P. Karnaukh and Iryna O. Dzera also conducted research on property and inheritance rights in the context of European integration. A comparison of property rights in the civil law of Ukraine and legislative acts of the countries of the European Union is carried out. The authors analysed the two principles of European property law, namely the principle of concreteness and the principle of openness and transparency, and how these principles can be integrated into Ukrainian society. Trends in the reform of property rights both in Ukraine and in European countries are presented.

Yurii D. Prytyka, Mykhailo M. Khomenko and Ievgeniia A. Bulat studied the re-codification of civil legislation regarding the concept of civil liability. The material makes a contribution to the systematisation and analysis of, and the search for, solutions to problems in the civil legislation of Ukraine such as exemption from civil liability, the introduction of the institution of collective legal protection, determination of the structure of non-contractual obligations, and rethinking approaches to the regulation of contingent liabilities.

The processes of European integration in the contract law of Ukraine are considered by Volodymyr V. Luts, Andrii B. Hryniak, Mariana D. Pleniuk and Valeriia $\mathrm{V}$. Krykoves. In the study, with the use of the modelling method, the issues of contractual regulation of private law relations in Ukraine and the countries of the European Union are examined. Attention is focused on the implementation of the European methodology of compulsory law. Also, in their study, the authors both present methods whereby the role of the contract in civil relations can be increased, and assess the need for the priority of individual regulation of contractual obligations. Sadly, Volodymyr V. Luts passed away prior to the publication of this issue. This is an unexpected tragedy for all members of the Academy, and we mourn his loss.

Viktoriia O. Khomenko, Leonid V. Efimenko and Valentyna A. Vasilyeva studied the legal status of the enterprise after a decision is taken to terminate it. The authors investigate how legal entities are liquidated in accordance with the codes of Ukraine and the European Union. Problems are raised in terms of the activities of liquidation commissions and the shortcomings of the civil legislation of Ukraine in matters of state registration of legal entities. The relevance of the study is explained by the fact that entrepreneurial activity is one of the main factors in the development of innovative industries and the market economy of Ukraine.

Ganna V. Buiadzhy raises the problem of regulation of confidential management and trust ownership in the civil law of Ukraine. The study describes the specificity of contractual relations of subjects of civil law in the management of securities. In addition, the work studies trust constructions such as the property management institution and trust property. A special place in the article is 
occupied by the study of the experience of trust structures in Ukrainian legislation and legislative acts of the countries of the European Union.

Vyacheslav I. Truba, Lyudmila M. Tokarchuk and Stella Ye. Morozova pay special attention to the integration of family law in Ukraine in accordance with the principles of legislative regulation of family relations in European countries. Trends in the development of family values in society and whether the legislative acts correspond to the present ones are studied. Particular attention is given to the study and reflection of the principles of family law in the Constitution of Ukraine and the Family Code of Ukraine.

Arbitrary interference with human rights by the judiciary has been studied by Svyatoslav A. Slipchenko, Oleh V. Syniehubov, Aleksandr R. Shyshka and Vikoriia V. Valakh. The paper analyses the decisions of the European Court concerning the infringement of human rights by the judiciary. The authors emphasise that the solution to this issue in Ukraine is a necessary component of a democratic society, as well as confirmation of human rights guarantees.

Svitlana S. Bychkova, Nataliia V. Bilianska and Tetiana R. Fedosieieva have developed recommendations for improving the legislation of Ukraine in the field of inheritance rights. The authors conduct a comparative analysis of inheritance rights in the countries of the European Union. It is proven that it is necessary to add a number of points into the Ukrainian legislation, which take into account the modern possibilities of reproductive medicine. Attention is also paid to how the right to inheritance is regulated at the theoretical and practical levels.

The protection of intellectual property rights is the subject of study by Volodymyr M. Kossak, Ihor Ye. Yakubivskyi and Mykola V. Oprysko. They analysed the methods of securing intellectual property rights in the Civil Code of Ukraine and in the agreements of the Association of the European Union and the Eurasian Economic Union. As a result of the study, the authors make conclusions on the necessity of recodifying the Civil Code of Ukraine, taking into account the experience of European countries regarding the quality assurance of intellectual property rights.

These studies clearly indicate the need to recodify the Civil Law of Ukraine. This is one of the important steps towards the European integration of Ukrainian society. But another important step is the observance of these provisions in everyday life by the authorities, legal entities and individuals. 